August 2011

\title{
Healing Psychosocial Trauma in the Midst of Truth Commissions: The Case of Gacaca in Post-Genocide Rwanda
}

Regine U. King

Follow this and additional works at: https://digitalcommons.usf.edu/gsp

\section{Recommended Citation}

King, Regine U. (2011) "Healing Psychosocial Trauma in the Midst of Truth Commissions: The Case of Gacaca in Post-Genocide Rwanda," Genocide Studies and Prevention: An International Journal: Vol. 6: Iss. 2: Article 5.

Available at: https://digitalcommons.usf.edu/gsp/vol6/iss2/5

This Articles is brought to you for free and open access by the Open Access Journals at Digital Commons @ University of South Florida. It has been accepted for inclusion in Genocide Studies and Prevention: An International Journal by an authorized editor of Digital Commons @ University of South Florida. For more information, please contact digitalcommons@usf.edu. 


\title{
Healing Psychosocial Trauma in the Midst of Truth Commissions: The Case of Gacaca in Post-Genocide Rwanda
}

\author{
Regine U. King \\ Factor-Inwentash Faculty of Social Work, University of Toronto
}

\begin{abstract}
Post-conflict governments and multilateral organizations have advocated truth commissions since the end of the Cold War. The mandate of truth commissions has been to combine the rule of law with psychosocial goals in the hope that they will break systemic cycles of violence and facilitate reconciliation. While these commissions emphasize the dimensions of truth telling, apology, forgiveness, and reconciliation, in practice, they are often challenged to fulfill the mandate of healing psychosocial traumas through these dimensions in countries that suffer not only from the traumatic experience of wars and genocide, but also from the multiple psychosocial issues that result from these forms of mass violence. The present article examines the psychosocial role of gacaca, a form of truth commission that was introduced in post-genocide Rwanda in 2002, and argues that relying on gacaca alone to heal psychosocial trauma in Rwanda underestimates the depth of suffering that genocide created both at the individual and collective levels in Rwandan communities. Writing as a Rwandan community-based mental health researcher and practitioner concerned with the mental well-being of individuals and communities that survive mass violence and genocide, I suggest that wellassessed models adapted to the issues at hand should be considered to promote the healing of psychosocial wounds and supplement the work of gacaca in the rebuilding of peace and reconciliation in the country and in similar contexts elsewhere. Mental well-being is central to the sustainable rebuilding and development of countries recovering from wars and genocide.
\end{abstract}

Key words: truth commissions, gacaca, healing psychosocial trauma

\section{Introduction}

In a period of only 100 days, an estimated 800,000 Tutsi were murdered by their Hutu neighbors in Rwanda. People were subjected to acts of physical and emotional cruelty, rape, body mutilation, coerced participation in the murder of loved ones, and forced mass displacement from their communities. Further, the genocide destroyed many other aspects of life including the social networks that used to protect Rwandans in times of adversity. Today, more than a decade later, Rwandans continue to face multiple serious social issues including poverty, HIV/AIDS, collective trauma, injustices, and interethnic tensions.

In 2002, Rwanda introduced the gacaca program as a form of truth commission in the attempt to address both the legal and psychosocial consequences of the genocide. Gacaca, which literally means "grass," was used traditionally as a Rwandan justice mechanism for dispute resolution to address issues related to property matters,

Regine U. King, "Healing Psychosocial Trauma in the Midst of Truth Commissions: The Case of Gacaca in Post-Genocide Rwanada." Genocide Studies and Prevention 6, 2 (August 2011): 134-151. (C) 2011 Genocide Studies and Prevention. doi:10.3138/gsp.6.2.134 
inheritance, and family law. ${ }^{1}$ While the new form of gacaca has received praise for being a home-grown approach, its ability to meet the psychosocial mandate has been questioned.

The topic of truth commissions and their workings has been extensively discussed. The purpose of the present article is to expand our understanding of the healing of psychosocial trauma through the different dimensions of truth commissions in non-Western post-conflict situations and, in particular, the gacaca courts in Rwanda. Although my aim is to demonstrate the challenges and limitations of healing psychosocial trauma and offer some suggestions, my critical approach does not intend to in any way minimize the role gacaca has played in the political and economic restructuring of the country. Rather, I hope to raise awareness about the dangers of placing unrealistic expectations on these commissions and assuming that once they complete their work the affected individuals and communities will be able to heal their psychosocial wounds. There is no magic bullet to make this happen.

The analysis and information shared in this article are both personal and academic. I am a genocide survivor born and raised in Rwanda. After the genocide, I worked in the mental health sector in Rwanda before I moved to Canada in 2000. I have followed the gacaca courts very closely through regular contacts with family, friends, and colleagues, some of whom were directly involved in the preparation and execution of the gacaca courts. I have traveled back to Rwanda every year and was able to hear and read about what was happening in the country. I am a $\mathrm{PhD}$ candidate focusing on community-based mental health research with an interest in alternative models to individual-based approaches.

Wars and genocide create deep emotional and psychosocial wounds that require well-examined techniques and skills and an extended period of time, all of which must extend beyond the limited mandate of truth commissions and gacaca in particular. Psychosocial trauma in post-conflict situations can be understood from a structural violence framework in that it combines individual emotional wounds with the social suffering of communities. Psychosocial trauma links feelings about a past traumatic experience of violence to issues of victimhood, guilt, and fear, which characterize post-conflict situations. ${ }^{2}$ It encompasses the struggles of individuals and collectives for systemic social transformation. ${ }^{3}$ When these struggles are nationwide and affect different levels of social structures, a more holistic approach is advised. ${ }^{4}$ As several scholars have shown, the immense and extremely complex psychosocial issues observed in non-Western post-conflict situations extend beyond individual suffering, but there has been a lack of models addressing individual and collective issues together. The following section provides more details about healing psychosocial trauma through truth commissions.

\section{Healing Psychosocial Trauma through Truth Commissions}

Wars and genocide result in major social issues-such as extreme poverty, physical injuries, continued injustice, and violence-that often contribute to the deterioration of the mental well-being of affected individuals and communities. Despite the staggering effects of mass violence, there has been a scarcity of mental health interventions in many non-Western post-conflict situations, including the Rwandan Genocide. The few existing interventions have been largely initiated and managed by nongovernmental organizations (NGOs) which operate with limited mandates. These organizations have also been criticized for applying individual-based models that are insensitive and inappropriate to the conditions of post-conflict societies. 
Truth commissions have been suggested as an alternative model to address these gaps through their dual retributive and restorative approach. These commissions are the most commonly used model of transitional justice that has been advocated by post-conflict governments and multilateral organizations since the end of the Cold War. ${ }^{5}$ The mandate of truth commissions is to combine the rule of law with psychosocial goals in the hope that they will break systemic cycles of violence and facilitate reconciliation. ${ }^{6}$ These commissions have been implemented in Latin American and Eastern European countries and in African countries such as South Africa, Sierra Leone, and Rwanda. Very recently, Canada also welcomed the truth-commission approach to deal with the historic violence committed against the Aboriginal peoples of Canada.

Truth commissions have become a well-established fixture on the global terrain of human rights, ${ }^{7}$ which suggests that countries should address past wrongs by acknowledging the pain inflicted upon a group or groups of citizens through brutality and violence. $^{8}$ Their dual role to address both legal and psychosocial trauma seemed ideal in many post-conflict situations. Although they may differ according to the particular conjunction of the political, cultural, and historical context of each country, they all tend to emphasize the dimensions of truth telling, apology, forgiveness, and reconciliation. Gacaca shared these concepts with other truth commissions in its mandate to heal and reunite Rwandans.

\section{Healing Psychosocial Trauma through the Renewed Gacaca}

Gacaca was inspired by the Truth and Reconciliation Commission (TRC) in South Africa in its legal and non-legal objectives. When the idea was introduced in Rwandan communities, both ordinary men and women and local government leaders found the hybrid nature of gacaca to combine legal and psychosocial objectives through truth telling, peace, justice, healing, forgiveness, and reconciliation to be very appealing. ${ }^{9}$ For the first time since the end of genocide, a more familiar concept was brought to their attention and ordinary Rwandans were asked to play an active role in it. Rwanda, like other nations that witnessed persistent occurrences of violence, has been categorized as a distressed and traumatized country alongside its citizens. Since the end of genocide, many programs were conceptualized and supervised by international organizations, excluding many Rwandans from the decisions about the issues that concerned them in the first place. Programs that were initiated by Rwandans tended to be considered illegitimate by people in positions of power and international funders.

Many Rwandans were optimistic about the gacaca concept. Both Hutu and Tutsi had high expectations for it; they hoped it could bring them back together and help restore relationships. On the one hand, Tutsi survivors wished to know details about how and where their family members had been killed and who had killed them. They also wanted to at least have the perpetrators admit what they had done and apologize. The Hutu also welcomed the gacaca idea and contributed to information gathering in the hope that the truth would come out, set the innocent free, oblige the guilty to acknowledge the suffering of the victims, who would offer forgiveness before guaranteeing a reduced sentence to those who confessed. ${ }^{10}$ Even those in jail expected repentance and forgiveness. Many mental health practitioners like me and some of the leading scholars in the field in Rwanda, such as Dr. Simon Gasibirege, judged gacaca to be a promising alternative approach to the imported models that tended to focus on the individual and ignore the collective nature of psychosocial trauma. 
In various villages in the country, informal gacaca gatherings similar to its traditional model started taking place for small acts such as looting and destroying property during the genocide. People were willing to do their part to repair some of the damage done between neighbors. They collaborated with government workers by providing information about what had happened during the genocide and participating in the election of the "inyangamugayo"- "the righteous" or those who were trusted to play the role of judges during gacaca. I personally participated in these elections and they seemed to be the most democratic elections I had ever attended. The candidates stood in front of the voters who lined up behind the candidate of their choice. Votes were counted and people went home peacefully. A good number of prisoners started providing information about the whereabouts of the people that they knew had been killed, and their surviving family members or former neighbors were able to uncover their remains and bury them with dignity.

Mental health professionals offered input into the mechanisms that they judged were needed to protect the mental well-being of Rwandans as they entered the process of remembering, recounting, and hearing traumatizing information during the hearings. ${ }^{11}$ Potential obstacles, especially the ability of the judges to handle the legal and moral aspects of gacaca, were critically debated and recommendations about the actions that could be taken before, during, and after the gacaca hearings were provided. ${ }^{12}$ The steps that were taken in preparation for the gacaca proceedings seemed to head in the right direction to heal and reunite Rwandans.

Government officials also had high hopes for gacaca and viewed it as a model by which to re-establish damaged relationships and unity. ${ }^{13}$ They wanted gacaca to be a Rwandan process governed by Rwandans-“a home-grown approach."

Although gacaca started as a grassroots approach governed by Rwandans in each community, it shifted perspectives during its implementation and integrated a new agenda to meet government demands. Over the course of the seven years since implementation, participation was no longer driven by the excitement and motivation that characterized the preparatory stage; it became a top-down approach ${ }^{14}$ and it faced increased suspicion and safety issues. Survivors who had hoped to share their suffering and other community members who had agreed to testify feared for their lives as they started receiving threats and experienced further exclusion. Many genocide suspects who had intended to confess started manipulating facts and evidence, which often resulted in a further prison sentence that could go up to 25 years. Those who were released on the condition of compensating the survivors for the material losses ended up doing community work, called "Travaux d'Intérêt Généraux" (TIG), which they resented and which did not benefit those who had lost everything to the genocide.

While the above realities might have benefited the government's political and economic restructuring, the gacaca implementation has not offered satisfying results to the mass Rwandan population or to outside evaluators who criticized gacaca for its limitations to carry out legal trials and its inability to reconcile Rwandans. Many of these critiques have often been directed at the Rwandan government and the model itself. Truth commissions are bound to fail when they are imposed from above.

In contrast with such criticism, I argue that the whole conceptualization of truth commissions is flawed in regard to the dual mandate of retribution and restoration. Inevitable incongruent expectations and weak outcomes result from the lack of clarity about activities that are organized to fulfill both the retributive and restorative goals. The lack of contextualization and consideration of the complex realities of the 
countries and communities in which truth commissions are implemented is also troubling because it can result in more harm than good. The following is an example of the complex contextual issues that I witnessed first-hand.

\section{First-hand Experience of Gacaca}

In the summer of 2007, I decided to attend a gacaca session. Many people I met over the course of that trip greeted me with statements such as "Did you know that this person has been released?" or "Today is a gacaca day and you cannot do anything today, you go to the hearings, or do nothing else." Once a week in every village, all work stopped so that all citizens can concentrate on the local gacaca hearings. The sense of urgency and concern in what I was hearing urged me to take part in what was happening. In order to gain a better understanding of these proceedings, I decided to attend gacaca in my home village. The community members had gathered in different neighborhood-based groups in various cells. After a long period dedicated to paperwork preparation and registration to ascertain who was present at the session, the villagers were instructed to sit in a circle in front of four judges to facilitate the process. Like in other communities, these judges had been elected by their fellow community members. A group of suspected perpetrators stood nearby. Some of them were prisoners dressed in pink uniforms and others were community members who had been listed as suspects but were still living in their respective communities.

The hearing on that day focused on four men accused of attacking the home of a woman of about 75 years of age at the time of the hearings. She had lost her husband and seven of her ten children. It was shocking to hear that one of her surviving children from a previous relationship with a Hutu man was among the accused. During the session, each of the accused men was asked to give a personal account of his role in what had happened to the woman. Their statements were more of a form of self-defense than a testimony. A few individual witnesses were then asked to either confirm or disconfirm the alleged facts. The elderly woman was among the witnesses and she seemed disoriented when judges asked her to focus on facts and not tell her story as she understood it. Although nobody seemed to deny what had happened to her and her family, there were problems in explaining how it had happened and who should be held responsible. For more than four hours, the community members witnessed the hearing in silence, moving their eyes back and forth between the accused and the witnesses. This sense of hopelessness was troubling because in other situations people do not stand by and watch emotionlessly; they do something about it. When I lived in Rwanda, some neighbors who wronged my family and felt guilty about what they had done expressed remorse in various ways (for example, by offering to help on the land, offering small gifts at a wedding, or returning stolen furniture). These cultural gestures offered a window for communication and they made us not feel so alone after the genocide. Other than a few survivors who guided the elderly woman from one group of defendants to the next and under the order of the judges, nothing else moved. Was the genocide experience being relived? Was this a conspiracy to silence or was it a silenced community in the face of the legality that tends to dominate social processes such as gacaca? Or was it dissociation from the agony felt around this community? This silent witnessing can be interpreted in different ways. As a Rwandan interested in the participatory and dynamic action of individuals and collectives for their healing, on that day, I witnessed a disciplined community rather than an active group of excited participants. 
This experience seemed to reflect the many stories I have heard from Rwandan women who confided in me that they were unable to bring up the issues that troubled them the most, such as rape, at these gacaca hearings. They were not allowed to say anything related to rape because doing so could lead the rapist génocidaire back to prison and in turn be considered as a crime committed by these women. Further, they did not see any support from the judges or other community members. This may explain the prevalence of many traumatic crises, suicidal attempts, and even occasional uncontrollable threatening statements during gacaca sessions instead of dialogical expressions. Silence is very damaging, especially for those whose suffering is not given value.

Scholars who examined the psychosocial aspects of truth commissions argue that gacaca did not result in positive outcomes, ${ }^{15}$ partly because of the top-down approach that the government adopted halfway through the hearings. Phil Clark, who spent an extensive period of time in Rwanda observing and recording the gacaca proceedings, offers evidence that the Rwandan government closely controlled the functioning of due process to the point of having officials intervene to correct the judges' statements, halt disruptive behavior in the general assembly, or interpret back to the participants what the testimonies meant. ${ }^{16}$ Although Clark judges that such actions were not generalizable, he acknowledges the impact that these interferences had on the desired open space in which dialogue was needed to enhance non-legal ends-the psychosocial goals of gacaca.

A close examination of truth commissions reveals that gacaca is not alone in the struggle to meet psychosocial needs. As the analysis of the different dimensions advocated by truth commissions will show, the inhibition of the psychosocial component is a commonly shared concern except in places where the locally initiated approaches assumed the risk of not seeking legitimacy from the top social structures of society (e.g., the Peruvian integration of the Senderistas in the Ayacucho region). ${ }^{17}$ To me, these concerns reside in the whole conceptualization of truth commissions, which combines retributive and restorative justice and fails to critically consider the meaning and implications of each dimension in the work of truth commissions.

In the following section I pay particular attention to these dimensions, including truth telling, apology, forgiveness, and reconciliation. Accountability, public acknowledgment, and apology are all forms of recognizing the wrong done and promising to not repeat past mistakes. I use apology as the term most commonly used in truth commissions. Reconciliation will not be examined as a separate concept because the other dimensions are part of the reconciliation process.

\section{Truth Telling}

Truth commissions have considered truth telling to be an important dimension of addressing the legal issues and psychosocial trauma that result from mass violence. With a concentration on truth telling, Alex Boraine postulates that the telling of stories about dehumanizing acts can be publicly received with dignity when relayed in a poignant manner. ${ }^{18} \mathrm{He}$ also asserts that truth commissions challenge people who deliberately ignore the suffering inflicted on others to stop saying that they did not know. ${ }^{19}$ Instead, they are offered the opportunity to cooperate with survivors who are seeking the truth about what happened to their loved ones. Cathartic reactions to testimonies are thought to facilitate the transition from a wounded to a healed individual; the effects of the testimonies presumably impact those who do not have a chance to testify. Truth telling is also believed to consist of narratives 
or expressions of a collectively shared understanding of the past gained from individuals' different levels of witnessing. ${ }^{20}$ However, Mendeloff argues that truth telling through testimonies is very hard to prove empirically because it is subjective; human beings always remember and relate stories from a spatially and temporally limited perspective. $^{21}$

From a political point of view, truth telling is a tool to break the cycle of silence surrounding mass violence so that people cannot claim ignorance. ${ }^{22}$ Pumla GobodoMadikizela argues that these commissions allow for a reflection on one's own role in the past and the capacity to confront and acknowledge the wrong done and, in turn, this should lead to reaching out to others in the attempt to repair broken relationships. Using the example of South Africa, she explains that the TRC created a space for people to come together to forge a peaceful society by sharing their pain, grief, anger, and resentment, emotions that are associated with a history of violence in a reflective dialogue. She adds that the public spaces open to the TRC hearings were sufficiently intimate to allow some acts of recognition, apology, and forgiveness. ${ }^{23}$ Michael Humphrey, on the contrary, finds troubling the adoption of psychoanalytic language which proposes that revealing is healing and that unresolved memory of past violence can be overcome by remembering, telling, and forgetting. ${ }^{24}$

According to my observations from gacaca and the anecdotal stories heard from people who have participated in it, telling and listening to testimonies was not done as a form of dialogue because it did not engage the community participants who witnessed in silence. It seemed to me that the environment was actually unsafe for those testifying and the defendants who had to prove their innocence in regard to the accusations made against them. When offering testimonies or defensive replies, the accused and the offended addressed the judges who had the ultimate power to decide the outcome of the proceedings.

Researchers who followed gacaca hearings in Rwanda and had opportunities to interview some of its participants reported that actually telling or giving testimony during the gacaca hearings had a negative impact on the psychological well-being of those involved. In a study conducted on gacaca, Katherine Brounéus demonstrates that survivors who testified in the gacaca were $20 \%$ and $40 \%$ more likely to suffer from depression and post-traumatic stress disorder (PTSD), respectively, than survivors who had not done so. Among the inyangamugayo (the judges) or neighbors, the effect of bearing witness emerged even more strongly as the relative risks of suffering from depression and PTSD, respectively, were 60\% and 75\% higher among those who had testified in the gacaca compared to those who had not. ${ }^{25}$ Participants also reported feelings of greater insecurity and fear after testifying as well as physical and other psychological difficulties immediately before, during, and after their testimonies, including shaking uncontrollably, fainting, and intense feelings of isolation. ${ }^{26}$

Studies on emotions such as shame and guilt have shown high patterns of unique relationships between emotions and motivations when participants were asked to recall "other-caused events," whereas feelings of anger, sadness, and anxiety were closely interrelated with the "self-caused event." 27 Similarly, in a case study concentrating on one particular community Max Rettig found that the healing aspect of truth telling was rather questionable as participants gave false testimonies to seek revenge for grievances related or unrelated to genocide. Rettig showed, for instance, that some community members wrongfully accused others as a result of marital affairs or land-based conflicts while others did it to avoid severe punishment or threats. $^{28}$ Of the three elements of truth telling, truth hearing, and truth shaping, 
Clark found truth telling to be the most problematic. Suspects and their allies told lies to protect themselves or their loved ones, simply hid evidence, or went even further to threaten survivors to not tell what they knew. ${ }^{29}$ Yet, there were no counselors available to support those who experienced emotional distress resulting from the gacaca hearings.

\section{Apology}

Apology is another concept that has been greatly emphasized in truth commissions as the morally "right thing to do." It consists of acknowledging injustice, expressing regret, and accepting responsibility, including material or financial compensation. Sincere apology is a critical factor in restoring broken relationships. ${ }^{30}$ According to Allan el al., genuine apology should go beyond general verbal apologies to incorporate apologetic behavior that reflects the wrongdoers' degree of sincerity as the victims perceive it. ${ }^{31}$ For full-fledged completion, a genuine apology must elicit acceptable signs of empathy on the part of the offended party. ${ }^{32}$ In the form of accountability, apology can range from sincere acknowledgment of the wrong done and expression of regret to material or monetary compensation or other forms of punishment, such as imprisonment.

While truth commissions place a great deal of emphasis on the process of apology, this concept has often been discouraged by a legal system in which offenders manipulate or deny facts in order to avoid any form of accountability. Concentrating on factual truth and other simple forms of public acknowledgment and reluctantly incorporating apologetic measures hinders the very nature of what apology means in a healing sense. ${ }^{33}$

In places like Peru, where the unrest is rooted in decades of animosity, compensation has been considered unreasonable. ${ }^{34}$ In other countries where truth commissions recognize the importance of material compensation, financial compensation is seldom provided as a form of recognition of the injustice and pain inflicted on the victims, with a common excuse of insufficient funds. In places where mass violence was sponsored by the state, financial apology is seen as the responsibility of the government (e.g., South Africa).

In gacaca courts, however, compensation has been a burden on individual offenders rather than the state. Because of the poverty of many of the frontline killers, individuals who cannot afford monetary compensation do community work, known as TIG, such as repair of the roads or other tasks related to the public interest and not to the individual victims, many of whom also live in extreme poverty. This approach has left both the victims and the perpetrators dissatisfied by the outcomes of gacaca, thereby creating the perception of another form of injustice. While community work is good for all, survivors resent the fact that the government has done very little to help them rebuild their lives and the houses that were destroyed during the genocide. At the same time, the accused resent and blame the victims for what they view as exploitative punishment. In this context, the process of apology becomes overwhelmed by emotions of fear, anger, and resentment, and has little social space to offer sincere apology and forgiveness.

Within the context of healing emotional wounds, the process of apology entails emotional work on the part of the different parties in the conflict, who must cope with guilt, shame, anger, and pity. ${ }^{35}$ The manner in which apology is expressed influences the nature of the response offered by the injured party. There is a lack of empirical studies on the process of apology in the context of truth commissions. 
However, studies done on the concept of apology in social contexts other than truth commissions show that when offenders deny their offense and try to justify their wrongdoing-or ignore, avoid, or exclude the offended-they develop instances of active or passive dissociation ${ }^{36}$ or disengagement. These attitudes may indicate a lack of accountability on the part of the perpetrators which, in turn, can evoke more negative reactions from the offended and augment threats to attempts at reestablishing peace.

Although many truth commissions are theoretically supposed to enhance apologetic statements, they do not offer the necessary circumstances for emotions to be expressed and processed so that genuine apology can take place. Rather, commissions often focus on testimonies, especially the perpetrators' accounts, to provide facts of the mass violence that occurred and not on the intense climate that testifying may create. Kanyangara et al.'s assessment of the emotional climate and intergroup perceptions involving a group of survivors and prisoners accused of genocide crimes in Rwanda showed that gacaca hearings heightened negative perceptions which then prevailed for an extended period of time. ${ }^{37}$ Emotions of sadness, fear, disgust, insecurity, and shame increased during the course of the hearings, especially for survivors. Prisoners who accepted their role in the genocide during gacaca hearings reported feeling an intensified sense of guilt.

Granting the perpetrators amnesty when their testimonies match the evidence sought by the commissioners has also posed problems and raised questions about whose justice is being sought. The amnesties are often detached from remorse for the violation of victims' rights. Nevertheless, the victims of violence are required to accept the amnesty, which creates another obstacle on the journey toward forgiveness and hinders opportunities to obtain the desired psychosocial relief and benefits.

Research shows that people who go through formalistic processes of apology such as amnesty or insincere apology may later regret having apologized or experience anger and protest their innocence by blaming the victims for the violence that occurred. ${ }^{38}$ Genuine apology constitutes an important foundation for forgiveness ${ }^{39}$ and a twoway emotional process of giving and receiving. The presumed offenders feel relieved when they are able to express their regrets and shame about the wrong done, and the offended similarly experience relief from the pain endured when their offenders genuinely admit the wrong done. Unfortunately, this mutual communion of pain and emotion that transforms the affected individuals into renewed individuals who can in turn share the gift of forgiveness is missing from many truth commissions including the gacaca courts.

\section{Forgiveness}

The topic of forgiveness has also been adopted as a dimension of truth commissions. Forgiveness and reconciliation, like truth telling and apology, are interpreted differently according to different disciplines such as theology and some branches of psychology, including social psychology and, more recently, peace psychology. From a psychosocial perspective, the concept of authentic forgiveness is embedded in inner and outer factors. In this section, I examine the factors that influence forgiveness both at the individual (inner) and external (outer) levels.

At the individual level, research identifies narcissism as a major intrinsic factor that hinders forgiveness and psychosocial well-being. ${ }^{40}$ Narcissistic individuals tend to concentrate their efforts on the self and self-interests. They are easily offended and often preoccupied with defending their rights and requiring legal justice to be 
rendered after harmful events. For the narcissists, transgression is a debt that must be paid and forgiveness is costly and morally unacceptable. Their unforgiving nature can lead to anger, anxiety, and other negative emotions, especially when society suggests acts of forgiveness after painful experiences. The interpersonal and psychological anxiety observed in narcissistic individuals tends to be negatively correlated with social connectedness ${ }^{41}$ and tends to make the narcissists prone to mental health issues.

At the external level, factors that influence forgiveness include sociocultural and political variables. One of the conditions of belonging to a certain group is to accept group behaviors and attitudes that separate. In-group and out-group categorizations consist of showing favoritism toward group members and denigrating members of the out-group. ${ }^{42}$ In such a context, forgiving someone from an opposing group can threaten in-group cohesion or the individual right to choice. Studies of in-group and out-group relations find the process of forgiveness to be influenced by the level of regard in-group members have for out-group members. Stangor et al., in fact, showed that belonging to a group with high negative attitudes toward members of the outgroup hinders the willingness to forgive. ${ }^{43}$

In the case of post-conflict situations, these categorizations are understood differently. When mass violence is conceptualized as a general human tragedy, people are more forgiving and less inclined to assign collective guilt to the opposing group. ${ }^{44} \mathrm{~A}$ recent study conducted by Cehajic et al. with high school and university students in Bosnia and Herzegovina showed that when students identified themselves as Bosnian they showed reduced social distance from the out-group, greater tendency toward forgiveness, and increased trust in the other group in conflict. ${ }^{45}$ In contrast, other studies found that competitive victimhood and a high level of in-group identification discourage the forgiveness of members of the out-group, especially when in-group membership has links with political membership. ${ }^{46}$

An empirical understanding of forgiveness is crucial to psychosocial healing in the work of truth commissions. However, this dimension tends to take a legal or theological approach without considering the psychological needs of those who are involved and the complexity of the issues at hand. For instance, although forgiveness is said to be a part of the work of truth commissions, it is often excluded from the planned activities of truth commissions. When it is used, it is driven by motives and outcomes other than that of healing emotional wounds. Chapman's study on the TRC showed that some people participated in the hearing because they wished to discover the truth about human rights violations and the perpetrators. Others testified to tell their stories, gain public acknowledgment, or have their names cleared. ${ }^{47}$ Clark, in his multiple interviews in Rwanda about gacaca, found that forgiveness was often performed through public confessions that involved the accused and the public prosecutor representing the state rather than the opposed parties in the conflict. ${ }^{48}$ While these types of apology are often viewed as symbolic, their genuineness is questionable when there is no dialogue between those involved in the process.

Gacaca encouraged people to reconsider their situations and role in the genocide and the process itself. Some may even have attended after going through a personal process in the attempt to overcome the hurt. However, these initiatives seem to have been dashed when offenders did not come forward to tell the truth and apologize. My brother, who was severely cut with machetes several times, attended a session in which the person responsible for his attack was being tried. When I asked him what it was like to stand face-to-face with a man who left him for dead, he told me the following: 


\begin{abstract}
Before I went to the gacaca, I traced the journey I took on the day I was attacked. Then I identified two people I needed to forgive if they accepted to receive my forgiveness: the woman who shouted when I tried to hide behind her hut, and the man who attacked me first with his machete.... [T] he woman came forward and kneeled down to apologize again and again. But the man lied and then did not make any effort to acknowledge what he did to me. I forgave the woman and took back my forgiveness from the man when he failed to express remorse.
\end{abstract}

Some people might have the ability to juxtapose positive emotions with the negative emotions associated with the offense, move past their negative emotions, and even establish peaceful coexistence with their offenders. This kind of forgiveness, however, is very fragile because the root problem of disagreement remains untouched. This kind of forgiveness does not provide a good foundation on which to rebuild strong relationships, and feelings of animosity can be easily revived toward self or others when there is no opportunity to hear how the damage done affects the lives of people in a conflict.

Other people use religious forgiveness to obtain peace, especially when forgiveness is motivated by the "forgive and forget" idea and when violence is committed by members of the same community. When forgiveness becomes imposed as a requirement for maintaining peaceful coexistence and fails to repair broken relationships between the offender and the offended, it lends to the fragile state of peace, in opposition to true forgiveness which allows negative emotions-such as anger, resentment, the desire for revenge, and other negative emotions toward the offender-to be released. ${ }^{49}$ True forgiveness goes beyond the exoneration of the out-group from past injuries with the expectation that direct engagement with the out-group and reconciliatory processes will follow. ${ }^{50}$

It is well known that in many divided societies people form new social categories based on shared experiences and other types of in-group identification such as ethnicity, race, or gender. The question to ask is whether truth commissions, in their mandate to facilitate forgiveness, try to minimize this divide between in-group and out-group membership. In many countries where truth commissions have been promoted there is a great emphasis on victims and perpetrators as two opposing groups in the conflict. This black and white dichotomy is problematic at times when the perpetrator in one incident becomes the victim in the other. To recall the elderly woman I mentioned earlier, her son who committed genocide was also a brother to the half siblings who were killed in the genocide. In situations such as this one, the hurt can be very deep and the accusations and defensive testimonies can complicate the gacaca process and cause further psychosocial problems.

The exploration of each of the above dimensions provides a theoretical and empirical understanding of the dimensions and the challenges they pose to the conceptualization and implementation of truth commissions. The lack of critical consideration of these dimensions has moral causes that are often ignored in the analysis of the truth commissions. These include false promises and a lack of concern about the impact of truth commissions on the psychosocial well-being of individuals and communities.

\title{
False Promises
}

False promises involve, simply put, promising things that truth commissions are unable to achieve. This practice is notable in the combination of retributive and restorative justice models-two approaches rooted in dichotomous philosophical frameworks. Retributive justice, rooted in legal justice and supported by the liberal human rights tradition, is not an equalizing discourse. Although this approach seeks 
to punish the offender and vindicate the victim, ${ }^{51}$ it does not always offer opportunities to explore the problems that caused violence or the resulting complex issues, such as psychosocial trauma. Restorative justice, on the other hand, originates from moral and religious discourse $\mathrm{s}^{52}$ and encourages the restoration of relationships and involves apology, forgiveness, and reconciliation between individuals and groups.

The combination of opposing perspectives in one intervention model has been considered a political strategy to manage post-conflict societies but is unsatisfying at the psychosocial level. In fact, in theory, truth commissions seem to lean toward a restorative approach. However, in practical terms, balancing retributive justice with restorative and reconciliation processes has been a struggle.

During the proceedings, gacaca became more retributive than restorative, and the collected facts were used to prosecute the wrongdoers rather than restore relationships through the processes of apology and forgiveness. Anecdotal reports about gacaca reveal that the complicated cases that lasted more than one session were often cases that presented complex legal challenges and not reconciliatory processes. While the initial preparatory activities tended to emphasize the restorative approach, gacaca was transformed over the course of its implementation into a topdown approach charged to meet the mandate of the state and not of the people. Consequently, it fell into the trap of state-driven goals imposed from above, which is common in many truth commissions. ${ }^{53}$

At the beginning, gacaca was praised for being unique in that it countered the top-down approach by involving the local population in electing their own judges, actively participating in the collection of facts, and testifying during the proceedings. ${ }^{54}$ Both Hutu and Tutsi were chosen as judges. While people tend to think that the implementation did not go so well, the conceptualization of gacaca also presented initial contradictions about what it ought to achieve and how it ought to do so.

For instance, the collection of facts was not as truthful as expected. ${ }^{55}$ The accused frequently gave evasive testimonies in order to cover up their own deeds or those of family members by admitting to minor crimes while attributing more serious violent acts to those who had died or disappeared. At the government level, the collection of facts about past wrongs contradicted the information that had been used to motivate people to participate in gacaca. The written objectives of this form of truth commission emphasized prosecution, ${ }^{56}$ whereas people were told that it was reconciliation that was being sought. These conceptual and practical contradictions are a reflection of the moral issues related to the whole process. It is of no surprise that those involved both locally and nationally said they were doing one thing while actually doing exactly the opposite of what was expected.

\section{Caring Less about Re-traumatization}

Asking people to relive traumatic experiences without adequate and appropriate support in place and trying to achieve on the social level what the psychological models attempt to accomplish on an individual level might actually be more traumatizing than healing. ${ }^{57}$ The TRC, which is upheld as a role model for other truth commissions, has itself been criticized for underestimating the extent of the psychological impact of public testimonies of the acts of violence committed during the apartheid regime in South Africa. ${ }^{58}$ According to Allan, the initial draft of the TRC did not have a plan to support witnesses who had to relive their traumatic past through testimonies. ${ }^{59}$ Even when the testimonies were recognized as potentially re-traumatizing and psychologists were invited to help, the support was restricted to individuals who had given testimonies and not those who heard them. In actuality, testimonies of 
mass violence can be traumatic for both the witnesses and the public who follow these unfolding stories in silence.

These testimonies can even have dramatic effects when the facilitators of the process, and judges in the case of gacaca, lack facilitation skills for complex and traumatizing processes (e.g., traumatic crises). In Rwanda, the elected judges received basic training in legal prosecution and not in healing processes and mediating complex cases. While this kind of training was in many ways insufficient and inadequate, it did not prevent the judges from making legal decisions that took precedence over the reconciliatory goals that the gacaca initiatives aimed to accomplish. Anecdotal evaluations of this process by older Rwandans who understood the difference between the old and new gacaca found the new one to be an instrument of the state influenced by international donors. Rather than a psychosocial grassroots intervention, gacaca, like many other truth commissions, became what Teitel calls "a bureaucratic response to bureaucratic murder" 60 that is driven by political and economic restructuring and governance.

In old gacaca, the neutral and respected members of the community who were invited to resolve a particular issue met at the scene where the wrong had been done. The process included hearing the explanations of the parties involved in the conflict, collecting factual evidence from observation, and hearing the testimony of witnesses. Rather than imposing punishment, the two parties were given an opportunity to express their feelings and needs, and through a negotiation process they agreed on compensation for the wrong done. Other community members were not silent witnesses. They participated in the discussions and even helped negotiate the compensation. If the offender did not have the means to compensate the victim for the wrong done, other members offered some assistance. Assessment of the wrong done was always followed by a recognition of responsibility and an apology. The process was accompanied by rituals of shaking hands and sharing a drink which was purchased by both parties and sometimes other community members. The restoration of the broken relationship was an important outcome of this old grassroots form of gacaca. The involvement of the community in the process was a sign of solidarity. The old gacaca model resembles other grassroot approaches observed in post-conflict countries, such as Peru, ${ }^{61}$ and East Timor's village-based Community Reconciliation Procedures (CRPs). ${ }^{62}$ Although these approaches tend to apply methodologies that bring local people together to challenge individual-based models and use sociocultural resources to repair the damage done, they often lack legitimacy and the methods they propose often remain understudied. The following section offers some suggestions on how psychosocial healing can be approached through an emphasis on grassroot-based truth commissions.

\section{Suggestions for Healing Psychosocial Trauma through Truth Commissions and Gacaca}

The action of remembering and telling stories of violence is necessary to stop the cycles of violence that threaten livelihood in post-conflict societies. Breaking the silence that surrounds mass violence through public testimonies is important both politically and socially. Truth commissions can continue to offer an alternative to individual legal and psychological approaches. The collection of stories of violence and the use of case presentations as a way to recognize the pain inflicted and the failure of the state to protect its citizens should be encouraged for public acknowledgment. However, the institution in charge of truth commissions in each country 
should focus on the needs of the people and determine what actions must be taken based on the results of assessments. This would limit unrealistic expectations and false hopes and allow the process to build on the local resources that can remain in place once the commissions complete their work.

Local governments and external supporters have the responsibility to ensure security and the rule of law and to acknowledge the impact of mass violence on the psychosocial well-being of individuals and their communities. Local people should be identified as key players in the healing of their own trauma and the rebuilding of their communities. Affected individuals need to be aware of the suffering of other community members on all sides of a conflict. The depth and extent of healing will depend to a high degree on the willingness of individuals to mobilize other community members and share resources through social and psychological group processes.

Initiating a truth commission managed by local citizens does not mean the local citizens in charge (i.e., judges elected for gacaca courts) need training only in legal matters, which tended to be the case in Rwanda. I suggest that the individuals trusted to be fair in their judgment should also receive other kinds of training that empower them to do their job right. One of the issues with which truth commissions have experienced difficulties is the ability to address the different forms of violence embedded in different levels of social structures. One way to address these forms of violence would be to encourage local people to identify equalizing coping mechanisms and rituals that extend beyond the borders of existing social categorizations. As explained above, in traditional gacaca some rituals were more restorative than the judgment itself. However, the renewed gacaca has tended to focus on what divides people rather than on what unites them. Rituals can facilitate the creation of the space needed for breaking the silence that paralyzes those whose identities have been violated and can enhance psychosocial healing.

\section{Conclusion}

In this article, I discussed the different dimensions that demonstrate the lack of careful conceptualization of truth commissions and gacaca in particular. Although some of these dimensions involve legal and psychosocial aspects (e.g., truth telling and different forms of accountability), each of them should be well-studied in terms of its legal and psychosocial aspects and within the context of the concerned postconflict society in order to set up appropriate and achievable objectives. The process of their implementation should also be carefully scrutinized and it should build on existing resources and mechanisms. For instance, some people had managed to settle some of the conflicts related to the genocide event by telling the truth about what happened, compensating according to one's means, and even repairing some broken relationships. The implementation of gacaca in each region should have used these instances as examples to encourage other community members to do the same.

On a concluding note, the healing of psychosocial trauma cannot start and finish with truth commissions or other imposed models. ${ }^{63}$ The different dimensions of truth commissions can help bring about justice and heal psychosocial trauma if carefully conceptualized and implemented. The active involvement of the local people and the use of local resources are crucial to the achievement of healing psychosocial trauma in post-conflict situations and post-genocide Rwanda. The creation of a contained space, the use of local unifying rituals that are oriented toward social justice, and good facilitation skills can help manage the overwhelming emotions and change affected communities from broken and divided ones into healing communities. 


\section{Notes}

1. William A. Schabas, "Genocide Trials and Gacaca Courts," Journal of International Criminal Justice 3, no. 4 (2005): 879-95.

2. Ignacio Martín-Baró, "War and the Psychosocial Trauma of Salvadoran Children," trans. Anne Wallace, in Writings for a Liberation Psychology, ed. Adrianne Aron and Shawn Corne (Cambridge: Harvard University Press, 1994), 119-21; Patrick Burgess, "Justice and Reconciliation in East Timor: The Relationship between the Commission for Reception, Truth and Reconciliation and the Courts," Criminal Law Forum 15, no. 1-2 (2004): 146-53.

3. Lubna Nazir Chaudhry and Corrine Bertram, "Narrating Trauma and Reconstruction in Post-Conflict Karachi: Feminist Liberal Psychology and the Contours of Agency in the Margins," Feminism and Psychology 19, no. 3 (2009): 298-312, 299-300.

4. Michael G. Wessells and Carlinda Monteiro, "Healing the Wounds following Protracted Conflicts in Angola: A Community-Based Approach to Assisting War-Affected Children," in Handbook of Culture, Therapy, and Healing, ed. Uwe P. Gielen, Jefferson M. Fish, and Juris G. Draguns (Mahwah, NJ: Laurence Erlbaum Associates, 2004), 321-41, 330.

5. Ruti G. Teitel, "Transitional Justice Genealogy," Harvard Human Rights Journal 16 (2003): 69-94, 78.

6. Mark R. Amstutz, The Healing of Nations: The Promise and Limits of Political Forgiveness (Lanham, MD: Rowman and Littlefield, 2005), 8.

7. Rosemary Nagy, "Transitional Justice as Global Project: Critical Reflections," Third World Quarterly 29, no. 2 (2008): 275-89, 276.

8. Elizabeth Stanley, "What Next? The Aftermath of Organised Truth Telling," Race and Class 44, no. 1 (2002): 1-15, 1.

9. Phil Clark, The Gacaca Courts, Post-Genocide Justice and Reconciliation in Rwanda: Justice without Lawyers (New York: Cambridge University Press, 2010), 33-46.

10. Timothy Longman, “An Assessment of Rwanda's Gacaca Courts," Peace Review 21, no. 3 (2009): 304-12, 306.

11. Simon Gasibirege, Santé Mentale Justice et Gacaca au Rwanda: Leçons d'une Pratique de Santé Mentale Communautaire pour l'Approche de la Prévention en Santé Mentale, 7-10 Novembre 2000.

12. Bureau d'Etude AVENIR, Plan Strategic d'Intervention Psychologisocial dans le Processus Gacaca, Report, 2002.

13. Clark, Gacaca Courts, 135.

14. Ibid., 146-47.

15. Karen Brounéus, "The Trauma of Truth-Telling: Effects of Witnessing in the Rwandan Gacaca on Psychological Health," Journal of Conflict Resolution 54, no. 3 (2010): 408-37, 409; Ervin Staub, "Justice, Healing and Reconciliation: How the Peoples' Courts in Rwanda Can Promote Them," Peace and Conflict: Journal of Peace Psychology 10, no. 1 (2004): 25-32, 27.

16. Clark, Gacaca Courts, 146, 217.

17. The villagers from the Ayacucho region decided to render justice and reintegrate former Senderistas in a rehabilitative manner instead of handing them over to the. Senderistas is the name of the guerrilla movement involved in ongoing fighting with the Peruvian government. The return to the community was facilitated through sharing accounts of the suffering the community experienced at the hands of the Senderistas and their own experiences in the mountains. A public commitment to never go back to guerrilla activities was obtained from the members of Senderistas who returned to the community. Although they received some form of physical punishment through a number of whippings, they were offered a piece of land on which to build a house and grow crops, and settle among other community members. For more details, see Kimberly Theidon, "Justice in Transition: The Micropolitics of Reconciliation in Postwar Peru," Journal of Conflict Resolution 50, no. 3 (2006): 433-57. 
18. Alex Boraine, “Transitional Justice: A Holistic Interpretation," Journal of International Affairs 60, no. 1 (2006): 17-28, 21.

19. Ibid., 21.

20. Pumla Gobodo-Madikizela, "Trauma, Forgiveness and the Witnessing Dance: Making Public Spaces Intimate,” Journal of Analytical Psychology 53, no. 2 (2008): 169-88, 176.

21. David Mendeloff, "Truth-Seeking, Truth-Telling, and Postconflict Peacebuilding: Curb the Enthusiasm?" International Studies Review 6, no. 3 (2004): 355-80, 374-76.

22. Boraine, "Transitional Justice," 22.

23. Gobodo-Madikizela, "Trauma, Forgiveness and the Witnessing Dance," 176.

24. Michael Humphrey, "From Terror to Trauma: Commissioning Truth for National Reconciliation," Social Identities 6, no. 1 (2000): 7-27, 9.

25. Brounéus, "The Trauma of Truth-Telling," 425-36.

26. Karen Brounéus, "Truth-telling as Talking Cure? Insecurity and Retraumatization in the Rwandan Gacaca Courts," Security Dialogue 39, no. 1 (2008): 55-76, 66-71.

27. Toni Schmader and Brian Lickel, "The Approach and Avoidance Function of Guilt and Shame Emotions: Comparing Reactions to Self-Caused Wrongdoing," Motivation and Emotion 30, no. 1 (2006): 43-56, 53-54.

28. Max Rettig, "Gacaca, Truth, Justice, and Reconciliation in Postconflict Rwanda," African Studies Review 51, no. 3 (2008): 25-50, 42-46.

29. Clark, Gacaca Courts, 209.

30. Gobodo-Madikizela, "Trauma, Forgiveness and the Witnessing Dance," 178.

31. Alfred Allan et al., "Exploration of the Association between Apology and Forgiveness amongst Victims of Human Rights Violations," Behavioral Sciences and the Law 24, no. 1 (2000): 87-102, 99.

32. Robin M. Williams Jr., The Wars Within: People and States in Conflict (New York: Cornell University Press, 2003), 277.

33. Miroslav Wolf, The End of Memory: Remembering Rightly in a Violent World (Grand Rapids, MI: Eerdmans Publishing, 2006), 28-30.

34. Jemima Garcia-Godos, "Victim Reparations in the Peruvian Truth Commissions and the Challenges of Historical Interpretation," International Journal of Transition Justice 2, no. 1 (2008): 63-82, 79.

35. David H. Brendel, "Psychotherapy and the Truth and Reconciliation Commission: The Dialectic of Individual and Collective Healing," in Trauma, Truth and Reconciliation: Healing Damaged Relationships, ed. Nancy Nyquist Potter (New York: Oxford University Press, 2006), 15-27, 15-16.

36. Mark R. Leary et al., "The Causes, Phenomenology, and Consequences of Hurt Feelings," Journal of Personality and Social Psychology 74, no. 5 (1998): 1225-37, 1233.

37. Patrick Kanyangara et al., "Collective Rituals, Emotional Climate and Intergroup Perceptions: Participation in Gacaca Tribunals and Assimilation of the Rwandan Genocide," Journal of Social Issues 63, no. 2 (2007): 387-403, 398-400.

38. Julie J. Exline, Lise Deshea, and Virginia Todd Holeman, "Is Apology Worth the Risk? Predictors, Outcomes, and Ways to Avoid Regret," Journal of Social and Clinical Psychology 26, no. 4 (2007): 479-504, 499.

39. Michèle Girard and Etienne Mullet, "Propensity to Forgive in Adolescents, Young Adults, Older Adults, and Elderly People," Journal of Adult Development 4, no. 4 (1997): 209-20, 219.

40. Julie J. Exline et al., "Too Proud to Let Go: Narcissistic Entitlement as a Barrier to Forgiveness," Journal of Personality and Social Psychology 87, no. 6 (2004): 894-912, 908-9.

41. Richard M. Lee and Steven B. Robbins, "The Relationship between Social Connectedness and Anxiety, Self-esteem, and Social Identity," Journal of Counseling Psychology 45, no. 3 (1998): 338-45, 343-44. 
42. Americus Reed II and Karl F. Aquino, "Moral Identity and the Expanding Circle of Moral Regard Toward Out-Groups," Journal of Personality and Social Psychology 84, no. 6 (2003): 1270-86, 1271.

43. Charles Stangor, Gretchen B. Sechrist, and John T. Jost, "Changing Racial Beliefs by Providing Consensus Information," Personality and Social Psychology Bulletin 27, no. 4 (2001): 486-96, 493.

44. Michael J. A. Wohl and Nyla R. Branscombe, "Forgiveness and Collective Guilt Assignment to Historical Perpetrator Groups Depend on Level of Social Category Inclusiveness," Journal of Personality and Social Psychology 88, no. 2 (2005): 288-303, 300-301.

45. Sabina Cehajic, Rupert Brown, and Emanuele Castano, "Forgive and Forget? Antecedents and Consequences of Intergroup Forgiveness in Bosnia and Herzegovina," Political Psychology 29, no. 3 (2008): 351-67, 361-64.

46. Masi Noor, Rupert Brown, and Garry Prentice, "Prospects for Intergroup Reconciliation: Social-Psychological Predictors of Intergroup Forgiveness and Reparation in Northern Ireland and Chile," in Social Psychology and Intergroup Reconciliation, ed. Arie Nadler, Thomas Malloy, and Jeffrey Fisher (Oxford: Oxford University Press, 2008), 97-115, 106.

47. Audrey A. Chapman, "Truth Commissions and Intergroup Forgiveness: The Case of South African Truth and Reconciliation Commission," Peace and Conflict 13, no. 1 (2007): 51-69, 56.

48. Clark, Gacaca Courts, 297.

49. Ervin Staub, "Reconciliation after Genocide, Mass Killing, or Intractable Conflict: Understanding the Roots of Violence, Psychological Recovery, and Steps toward a General Theory," Political Psychology 27, no. 6 (2006): 867-94, 886-87.

50. Noor et al., "Prospects for Intergroup Reconciliation," 106-7.

51. Daniel Philport, "What Religion Brings to the Politics of Transitional Justice," Journal of International Affairs 61, no. 1 (2007): 93-111, 95-96.

52. Ibid., 96.

53. Bert Ingeleaere, "The Gacaca Courts in Rwanda," in Traditional Justice and Reconciliation after Violent Conflict: Learning from African Experiences, ed. Luc Huyse and Mark Salter (Stockholm: International Institute for Democracy and Electoral Assistance, 2008), 44; Nagy, “Transitional Justice," 276.

54. Schabas, "Genocide Trials," 893.

55. Ingeleaere, "Gacaca Courts in Rwanda," 57-58.

56. Gacaca had the following objectives: (1) Find out the truth about what happened since residents will be called upon as eyewitnesses to the acts committed in their cells, and they will compile a list of victims and perpetrators; (2) accelerate the prosecution of genocide since those who know what happened will testify in the presence of their neighbors on the hills; (3) continue the eradication of the culture of impunity by using any method that makes it possible to identify a person who took part in the tragedy, since once the truth is known, none of those who were complicit will escape punishment, and the people will understand that an offense results in the conviction of the criminal without any exception whatsoever; (4) punish those who played a part in the tragedy, reconcile the Rwandans, and strengthen their unity since the gacaca jurisdictions' system will induce the residents of the same cell, sector, commune, and prefecture to collaborate in judging those who participated in the genocide, to discover the victims, and restore their rights to innocent people; and (5) prove the capacity of the Rwandan custom, since, although the cases that the gacaca jurisdictions will have to hear are different from those that are normally resolved within the gacaca framework, these jurisdictions fit well into the custom of settling differences by arbitration, even amicable arbitration. See Transitional National Assembly of Rwanda Adopted Organic Law (TNARAOL) no. 40/2000, 16 January 2001.

57. Alfred Allan, "Truth and Reconciliation: A Psycholegal Perspective," Ethnicity and Health 5, no. 3-4 (2000): 191-204, 195; Alfred Allan and Marietjie M. Allan, "The South African Truth and Reconciliation Commission as a Therapeutic Tool," Behavioural Sciences and 
the Law 18, no. 4 (2000): 459-77, 472; Mendeloff, “Truth-Seeking, Truth-Telling, and Postconflict Peacebuilding," 365.

58. Allan, "Truth and Reconciliation," 193.

59. Ibid.

60. Ruti R. Teitel, Transitional Justice (Oxford: Oxford University Press, 2000), 78, quoted in Michael Humphrey, "From Victimhood: Truth Commissions and Trials as Rituals of Political Transition and Individual Healing," The Australian Journal of Anthropology 14, no. 2 (2003): 171-87, 175.

61. See note 17.

62. The CRPs were initiated in East Timor after the war between East Timor and Indonesia. During the war, Indonesia hired East Timorese to carry out violence against their own fellow citizens. They participated in the killing and looting of their own villages. The CRPs' objective was to bring victims, perpetrators, and other community members together to undertake acts of reconciliation. The majority of perpetrators tried by the CRPs came from the same villages as their victims. On their release, they were allowed to request to be re-accepted into their communities. Hearings were facilitated by a committee formed by a panel of local church and spiritual leaders and elders and chaired by a regional commissioner appointed by the East Timor government. Perpetrators were required to listen to their victims' stories, be confronted face to face with the pain and anger they caused, and given the opportunity to apologize. Punishment to restore some of the damage to the individual and community (e.g., building a school or paying back the stolen property) was decided by the community, and perpetrators had to comply. The hearings were completed by traditional ceremonial practices that included communal chewing of betel nut on a large mat before sending the final agreement to the district court for registration.

63. Stanley, "What Next?" 3. 